
VOLUME 10 NOMOR 6 DESEMBER 2021

ISSN : 2303-1514 | E-ISSN : 2598-5949

\title{
ANALISIS POLA ASUH ORANG TUA YANG BEKERJA TERHADAP PEMBENTUKAN MORAL KEJUJURAN ANAK
}

\author{
Rosiana $^{1}$, Irfai Fathurohman ${ }^{2}$, Mohammad Syaffruddin Kuryanto ${ }^{3}$ \\ $\mathbf{1 , 2 , 3}$ Universitas Muria Kudus, Kudus, Indonesia \\ ${ }^{1}$ rosiana1223@gmail.com, ${ }^{2}$ irfai.fathurohman@umk.ac.id, ${ }^{3}$ syafruddin.kuryanto@umk.ac.id
}

\section{ANALYZING PARENTING STYLES OF WORKING PARENTS ON SHAPING THE CHILDREN'S HONESTY}

\begin{tabular}{|c|c|}
\hline ARTICLE HISTORY & ABSTRACT \\
\hline $\begin{array}{l}\text { Submitted: } \\
10 \text { Oktober } 2021 \\
10^{\text {th }} \text { October } 2021\end{array}$ & $\begin{array}{l}\text { Abstract: This study aimed to find out the parenting styles of working parents on shaping } \\
\text { children's honesty. This research used a qualitative approach and the type of case study } \\
\text { research conducted at grade V SDN } 3 \text { Mayonglor, Kecamatan Mayong, Kabupaten Jepara. } \\
\text { The respondents were students, their parents from several different occupations, and teachers. } \\
\text { The data were collected thorugh unstructured observation, unstructured interview, and } \\
\text { documentation. The data analysis used was descriptive qualitative data analysis. Based on the } \\
\text { results of research, it was found that: 1) the parenting style in families with different types of } \\
\text { work included: democratic and authoritarian. Whereas, with the regard to students' moral, the } \\
\text { researcher focused on honesty. It was found that the children's honesty still needed to be } \\
\text { improved. Thus, it was suggested for parents to provide appropriate parenting styles for the } \\
\text { children to shape and improve the honesty for their children. }\end{array}$ \\
\hline
\end{tabular}

Keywords: parenting, working parents, honesty

Accepted:

29 November 2021

$29^{\text {th }}$ November 2021

Published:

27 Desember 2021

$27^{\text {th }}$ December 2021

\begin{abstract}
Abstrak: Penelitian ini bertujuan untuk mengetahui pola asuh orang tua yang bekerja terhadap pembentukan moral kejujuran anak. Penelitian ini adalah menggunakan pendekatan kualitatif dan dengan jenis penelitian studi kasus yang dilakukan di kelas V SDN 3 Mayonglor, Kecamatan Mayong, Kabupaten Jepara. Responden yaitu siswa, orang tua siswa dari jenis beberapa pekerjaan yang berbeda, dan guru. Pengumpulan data yaitu observasi tak berstruktur, wawancara tak berstruktur, dan dokumentasi. Analisis data yang digunakan yaitu analisis data deskriptif kualitatif. Berdasarkan hasil penelitian yang dilakukan analisis pola asuh orang tua yang bekerja terhadap pembentukan moral kejujuran anak adalah: 1) Bentuk pola asuh pada keluarga dengan jenis pekerjaan yang berbeda yaitu demokratis dan otoriter. Sedangkan berkaitan pada moral siswa, peneliti mengambil fokus pada moral kejujuran. Pada moral kejujuran anak masih perlu ditingkatkan lagi. Saran untuk orang tua dalam penelitian ini diharapkan dapat memberikan pola asuh yang tepat pada anak dan dapat membentuk serta meningkatkan moral kejujuran pada anak dengan lebih baik.
\end{abstract}

Kata Kunci: pola asuh, orang tua bekerja, moral kejujuran

\section{CITATION}

Rosiana., Fathurohman, I., \& Kuryanto, M.S. (2021). Analisis Pola Asuh Orang Tua Yang Bekerja Terhadap Pembentukan Moral Kejujuran Anak. Primary: Jurnal Pendidikan $\begin{array}{lllll}\text { Guru Sekolah Dasar, } 10 \quad \text { (6), } & 1599-1609 . & \text { DOI: }\end{array}$ http://dx.doi.org/10.33578/jpfkip.v10i6.8235.

\section{PENDAHULUAN}

Orang tua mempunyai tugas dan tanggung jawab yang sangat mulia dalam menghasilkan generasi-generasi manusia yang memiliki kepribadian yang bermoral tinggi.
Ayah merupakan seorang teladan pemimpin rumah tangga dalam mengatur dan membimbing keluarga. Sedangkan ibu merupakan tempat utama bagi anak-anaknya, sebab ibu yang mendidik seorang anak dari 
sejak dalam kandungan dan melahirkan hingga merawat sampai dewasa. Keluarga menurut Lickona (2012:48) mengatakan bahwa keluarga sebagai media sosialisasi terbaik yang sangat berpengaruh bagi anak-anak dalam pendidikan moral. Orang tua memiliki peran pola asuh dan pengaruh yang besar dalam mendidik, membimbing, dan mengawasi setiap perkembangan anak dalam kehidupan seharihari. Menurut Reskia, et al (2014:83) mengungkapkan bahwa orang tua adalah pendidik pertama sebab kedua orang tua yang pertama kali mendidik anaknya yang diberikan orang tua sebagai dasar yang sangat penting dalam menentukan perkembangan anak selanjutnya. Kedua orang tua merupakan teladan untuk anak-anaknya dalam berperilaku berakhlak mulia. Baik dan buruk moral anak pada waktu dewasa nanti tergantung kepada penanaman pembentukan moral anak yang diberikan oleh orang tuanya sejak kecil.

Anak diberi dididikan oleh orang tua dengan nilai-nilai moral yang baik maka akan menghasilkan generasi anak-anak yang memiliki akhlak yang baik dan benar. Seseorang bisa dikatakan mempunyai moral yang baik jika bertingkah laku sama dengan kaidah moral yang ada dan sebaliknya apabila tingkah laku individu tidak sama dengan kaidah yang sudah ada, maka dapat dikatakan tidak bermoral (Fathurrohman, 2019:80). Pembentukan moral anak jika dimulai sejak kecil sudah ditanamkan dan dipraktikkan dalam kehidupan sehari-hari dengan memberikan keteladanan langsung melalui perbuatan orang tuanya maka anak secara tidak langsung akan mampu menjadi seorang manusia yang bermoral. Jika anak laki-laki atau perempuan yang sejak kecil tidak ditanamkan nilai-nilai moral akan menjadikan anak tersebut bisa salah jalan dalam berperilaku, berbuat sesuka hati tanpa memperdulikan perasaan orang lain dan membuat tindakannya tidak sejalan dengan pikirannya.

Berkaitan dengan orang tua yang bekerja. Orang tua yang bekerja merupakan orang tua baik ayah maupun ibu di keluarga yang bekerja. Pekerjaan menurut pendapat Hasanah (2019:16) mengatakan bahwa pengertian pekerjaan orang tua yaitu suatu kegiatan orang tua baik ayah maupun ibu yang dilakukan dalam mendapatkan penghasilan. Seorang ayah memiliki tanggungjawab yang sangat besar untuk mencari nafkah dalam memenuhi segala kebutuhan keluarga baik yang kebutuhan primer maupun sekunder. Di era zaman modern sekarang tidak hanya ayah saja yang mempunyai pekerjaan, namun seorang ibu juga ada yang memiliki pekerjaan. Pekerjaan dilakukan demi untuk keberlangsungan bertahan hidup.

Adanya pekerjaan yang dimiliki setiap orang tua tanpa sadar membuat waktu yang dimiliki untuk anak tersita atau kurang terhadap untuk lebih memperhatikan anaknya. Salah satunya yaitu perhatian orang tua pada anak dalam pembentukan moral anak. Pekerjaan orang tua sering memiliki kesibukan sebab pekerjaanya sehingga sampai tidak sengaja atau lupa pada tanggung jawabnya terhadap memberikan pendidikan pembentukan nilai-nilai moral yang sangat penting bagi anak baik di dalam lingkungan keluarga, lingkungan di sekolah, lingkungan di masyarakat, dan dimanapun berada nantinya. Tidak sengaja atau lupa tersebut dikarenakan orang tua tidak mempunyai banyak waktu untuk anaknya dalam mendidik atau memperhatikan. Peristiwa tersebut terjadi terkadang dikarenakan oleh pekerjaan orang tua yang memerlukan dari waktu pagi sampai sore hingga bahkan sampai malam. Hal yang terjadi akhirnya orang tua tidak memiliki banyak waktu untuk mengasuh, mendidik, dan membimbing perkembangan anaknya. Banyak orang tua yang bekerja keras untuk kebahagiaan anak-anaknya, agar dapat memenuhi segala kemauan anak pada materi. Namun terkadang orang tua melupakan yaitu kebutuhan anak dalam bimbingan yang terpenting dalam pembentukan moral anak. Akibatnya jika pembentukan moral anak diremehkan, maka perilaku anak akan kurang 
baik. Pembentukan moral anak yang terima pada anak akan cenderung kurang maksimal. Orang tua yang keduanya sama-sama bekerja yaitu ayah dan ibu yang bekerjanya diluar rumah, seringkali anaknya menjadi kurang mendapat perhatian. Ketika anak pulang sekolah dan kedua orang tuanya tidak ada di rumah karena masih bekerja membuat anak merasa kesepian dan bebas melakukan apa saja. Ada juga orang tua yang menitipkan anaknya setelah pulang sekolah ke saudaranya, nenek atau kakeknya atau pembantu yang berada di rumah. Walaupun begitu anak tetap merasa kesepian, kurang bimbingan, pengawasan, dan perhatian orang tua. Kurangnya pengawasan dan bimbingan orang tua pada anak, dapat membuat anak akan bertingkah laku berbuat sesukanya sendiri. Apabila anak tidak dibimbing dalam pembentukan moral sejak kecil, akibatnya bisa buruk dengan melakukan penyimpangan dalam aturan-aturan nilai moral.

Berdasarkan dari hasil observasi yang telah dilakukan oleh peneliti anak dari kelas $\mathrm{V}$ ada para orang tua yang memiliki pekerjaan sebagai pengrajin genteng, karyawan pabrik, pedagang, dan penjahit. Di wilayah mayong letaknya strategis membuat terbukanya banyak usaha dan lapangan pekerjaan menyebabkan kesempatan bagi laki-laki dan juga bagi banyak wanita atau ibu rumah tangga juga memiliki kesempatan mempunyai pekerjaan. Adanya memiliki pekerjaan ini menjadikan mereka sibuk dengan pekerjaannya sehingga orang tua hanya memiliki sedikit waktu dapat bersama anaknya dalam membimbing maupun memperhatikan anak-anaknya. Terdapat juga keluarga yang kedua orang tuanya sama-sama bekerja sehingga kurang bimbingan dari orang tua. Tetapi anak-anaknya sudah memiliki nilainilai pembentukan moral seperti berkata jujur, berperilaku baik, sopan santun dengan orang tua. Hal tersebut sudah termasuk dari kategori dari keluarga yang sudah baik. Perbedaan pembentukan moral yang terjadi pada anak terletak pada cara kedua orang tua dalam mengasuh. Jika kedua orang tua sama-sama memiliki pekerjaan tentunya akan berbeda dengan keluarga yang hanya ayah saja yang bekerja di dalam keluarga atau hanya ibu saja yang memiliki pekerjaan di dalam keluarga. Setiap keluarga memiliki latar belakang yang berbeda sehingga cara yang digunakan dalam setiap keluarga dalam mengasuh anak juga berbeda. Pekerjaan orang tua yang saat ini dijalani tentunya mereka punya cara tersendiri untuk menjalani kehidupan keluarganya.

Berdasarkan latar belakang yang telah dijelaskan di atas, maka penulis melakukan penelitian dengan rumusan masalah yang berjudul "Analisis pola asuh orang tua yang bekerja terhadap pembentukan moral kejujuran anak". Penelitian ini bertujuan untuk mendeskripsikan pola asuh orang tua yang bekerja terhadap pembentukan moral kejujuran anak di kelas V SDN 3 Mayonglor Jepara.

\section{KAJIAN TEORI \\ Pola Asuh Orang Tua}

Orang tua adalah seorang figur sentral untuk kehidupan anak, sebab orang tua sebagai lingkungan sosial pertama yang dikenal anak, seorang figur yang dapat menentukan dari kualitas hidup anak, dan seorang figur yang paling utama dekat dengan anak secara psikis ataupun fisik (Jamaluddin, 2013:135). Orang tua merupakan pendidik yang utama dan pertama untuk anak-anak mereka, sebab dari orang tua pertama kalinya anak-anak memperoleh pendidikan (Daradjat, 2012:35). Pola asuh orang tua adalah cara yang digunakan orang tua dalam mendidik, mengasuh, mengarahkan dan membimbing anak dengan konsisten untuk mencapai suatu proses pendewasaan dalam diri anak sesuai dengan nilai-nilai dan norma yang berada di masyarakat. Pola asuh dalam keluarga merupakan usaha orang tua dengan konsisten untuk membimbing dan menjaga anak dari sejak lahir sampai remaja (Djamarah:2017:50). Pola asuh orang tua merupakan suatu pola perilaku yang diterapkan kepada anak yang bersifat relatif tetap dari waktu ke waktu (Badria \& Fitriana, 2018:4). Pola asuh orang 
tua merupakan upaya dari orang tua dalam membantu anak untuk mengaktualisasikan dalam penataan lingkungan sosial, lingkungan fisik, suasana psikologis, pendidikan, sosiobudaya, dialog dan menentukan suatu nilai-nilai moral sebagai dari dasar berperilaku (Shochib, 2014:15). Ada tiga jenis pola asuh terhadap anak yaitu demokratis, otoriter, dan permisif. Pola asuh demokratis merupakan suatu pola asuh orang tua yang memprioritaskan untuk kepentingan anak, namun orang tua tidak ragu-ragu dalam mengendalikan anak (Azizah, 2019:332). Selanjutnya, Pola asuh otoriter adalah suatu pola asuh berdasarkan dengan aturan yang diterapkan dan memaksa anak dalam bersikap dan juga bertingkah laku sama dengan keinginan dari orang tua (Sari, 2020:77). Kemudian, pola asuh permisif merupakan suatu perlakuan yang dilakukan oleh orang tua dalam memberikan kepada anak kesempatan seluas-luasnya dengan tidak adanya batasan tertentu atau mengikat (Satrianingrum \& Andriyanti, 2020:241).

Ciri-ciri pola asuh demokratis antara lain: 1) memberi arahan tentang perbuatan baik yang dipertahankan dan yang tidak baik untuk ditinggalkan, 2) menentukan aturan dan kedisplinan namun juga mempertimbangkan supaya bisa dimengerti dan diterima oleh anak, 3) menciptakan suatu suasana komunikatif di keluarga, 4) menciptakan keharmonisan di keluarga (Sukamto \& Fauziah, 2021:924). Pola asuh otoriter memiliki ciri-ciri antara lain: 1) suka memberi hukuman, 2) kaku, 3) tegas, 4) cenderung mengekang keinginan anak, 5) anak kurang kasih sayang dan simpatik, 6) orang tua cenderung memaksa anak agar patuh dengan nilai-nilai yang orang tua terapkan dan orang tua mencoba membentuk tingkah laku yang sesuai dengan anak (Steward \& Koch, dalam Fidaus \& Kustanti, 2019:215). Pola asuh permisif mempunyai ciri-ciri antara lain: 1) orang tua kurang mengontrol anak, 2) bersifat bebas dan longgar, 3) anak cenderung kurang dibimbing, 4) tidak ada hukuman, 5) anak diberi kebebasan membuat keputusan sendiri (Mirantika, 2016:32).

\section{Bekerja}

Bekerja adalah suatu pekerjaan usaha yang dilakukan dan diperlukan oleh manusia untuk mencapai tujuan-tujuan yang ingin dipenuhi. Pekerjaan orang tua sebagai suatu kegiatan orang tua baik ayah maupun ibu yang dilakukan demi mendapatkan penghasilan (Hasanah, 2019:16). Pekerjaan adalah suatu tindakan atau kegiatan yang menghasilkan seperti berupa suatu materi. Orang tua yang bekerja melakukan kegiatan atau tindakan sesuai dengan kemampuan yang ditekuni sehingga menjadi suatu pekerjaan dalam mendapatkan penghasilan. Pekerjaan memiliki ketentuan seperti: keterampilan, kemampuan atau keahlian, sikap, pengetahuan dan lainlain. Kemampuan dapat menjadikan seseorang memiliki pekerjaan yang sesuai dengan bakat dan minatnya. Bekerja dilakukan manusia untuk mencari nafkah dalam memenuhi segala kebutuhan yang diperlukan untuk itu seseorang harus memiliki suatu pekerjaan tertentu. Dalam penelitian ini, data jenis pekerjaan orang tua siswa kelas $\mathrm{V}$ yang diambil antara lain: pengrajin genteng, karyawan pabrik, pedagang, dan penjahit.

\section{Moral}

Moral adalah nilai-nilai, aturan, adat istiadat, perilaku, sopan santun, tolok ukur mengenai hal baik dan buruk suatu kelakuan. Istilah moral menurut K.Bertens (2016:35) bahwa istilah moral mempunyai arti sama dengan etika, yaitu norma-norma sebagai pedoman untuk individu atau kelompok masyarakat untuk mengatur tingkah lakunya. Kejujuran sebagai dasar yang penting dalam terjalinnya suatu hubungan interaksi harmonis yaitu diantara individu maupun kelompok (Yasbiati, et al, 2019:102). Perkembangan moral menurut Adisusilo (2013:4) bahwa perkembangan moral adalah proses yang dinamis secara umum untuk setiap budaya. Moral berkembang sesuai rangkaian dalam 
tahap perkembangan psikologis. Dalam penelitian ini, peneliti fokus pada moral yaitu moral kejujuran dengan perpedoman pada indikator nilai moral kejujuran. Selanjutnya indikator nilai kejujuran antara lain yaitu: a) Bisa dipercaya, b) Mengucapkan sesuatu hal yang benar-benar terjadi, c) Meminta izin ketika akan meminjam barang orang lain, d) Mengakui kesalahan, e) Jika berbuat salah meminta maaf dan memaafkan teman yang bersalah, f) Tidak menukar tanpa izin barang punya sendiri dengan punya orang lain, g) Tidak mencontek, h) Tidak berbuat curang, i) Menepati janji (Dewayani, 2016:17).

\section{METODE PENELITIAN}

Pendekatan dalam penelitian ini yaitu menggunakan pendekatan penelitian kualitatif dengan pendekatan studi kasus. Penelitian kualitatif merupakan jenis penelitian yang menghasilkan suatu prosedur analisis yang tidak memakai prosedur analisis statistik atau cara kuantifikasi lainnya (Meleong, 2014:6). Studi kasus merupakan serangkaian kegiatan ilmiah yang dilakukan dengan secara intensif, terinci, dan juga mendalam tentang suatu program, peristiwa, dan aktivitas pada tingkat perorangan, kelompok, lembaga atau organisasi dalam mendapat pengetahuan mendalam tentang suatu peristiwa (Rahardjo, 2017:3). Pendekatan kualitatif pada pelaksanaannya memfokuskan penelitian dengan tujuan untuk mengungkapkan dan menjelaskan. Pendekatan kualitatif dengan memakai jenis penelitian studi kasus ini digunakan untuk mengungkap kejadian terhadap subjek peneliti. Oleh karena itu peneliti memakai metode studi kasus dalam mengumpulkan semua data-data tentang bentuk pola asuh orang tua yang bekerja terhadap pembentukan moral kejujuran anak. Tempat penelitian dilakukan di kelas V SDN 3 Mayonglor, Kecamatan Mayong, Kabupaten Jepara. Subjek dari penelitian ini yaitu 4 siswa kelas $\mathrm{V}$, orang tua siswa dari jenis pekerjaan yang berbeda, dan guru. Pengumpulan data pada penelitian ini yang digunakan yaitu observasi tak berstruktur, wawancara tak berstruktur, dan dokumentasi.

\section{HASIL DAN PEMBAHASAN}

Bentuk pola asuh orang tua yang bekerja terhadap pembentukan moral kejujuran anak. Hal tersebut setiap dari orang tua mempunyai berbeda-beda cara. Dalam penelitian ini jenis pekerjaan yang dimiliki orang tua berbeda-beda, ada orang tua yang bekerja di rumah dan ada orang tua yang bekerja di luar rumah. Jenis pekerjaan orang tua siswa antara lain: pengrajin genteng, pedagang, karyawan pabrik, dan penjahit. Berikut ini adalah uraian peneliti dari data yang ditemukan:

a. Pedagang

Ibu SS adalah seorang yang bekerja sebagai pedagang sembako, baik itu kebutuhan sehari-hari atau yang lain juga dan begitu juga suaminya yang juga bekerja. Cara ibu SS membagi waktu antara pekerjaan dengan anak yaitu kerja dari jam sekian sampai jam sekian (tidak menentu). Kemudian setelah kerja waktu untuk bersama anak. Beberapa hal diterapkan oleh orang tua dalam mengasuh anaknya. Kali ini pola asuh yang digunakan oleh orang tua yang bekerja sebagai pedagang sembako salah satunya ada ibu SS yang mengungkapkan bahwa:

"Harus ada peraturan dari orang tua. Peraturan melatih untuk disiplin yang terutama dimulai dari yang terkecil dulu, misalnya ibadah itu harus tepat waktu. Hubungan dan suasana di keluarga hangat dan saling mendukung satu sama lain. Memberi arahan kepada anak tentang perbedaan baik dan buruk, mana yang harus dipertahankan dan ditinggalkan. Memberi perhatian dan juga bimbingan kepada anak. Kita memberi perhatian pada yang terkecilkecil dulu, itu membawa dampak yang besar. Suasana dikeluarga komunikatif, soalnya kita kalau misalnya kumpul bersama juga berbagi cerita, ada apa- 
apa kita bicarakan jadinya itu kita tidak ada istilah rahasia-rahasiaan".

Berdasarkan hasil wawancara tersebut menunjukkan bahwa pola asuh yang diterapkan dalam keluarga tersebut adalah pola asuh demokratis. Pola asuh demokratis yang diterapkan oleh ibu SS dibuktikan ditandai dengan orang tua memberi peraturan kepada anak dengan tanpa paksaan, orang tua memberi arahan, perhatian, dan bimbingan kepada anak. Hasil observasi menunjukkan bahwa anak bebas dalam berkreatifitas, tingkah laku anak menjadi terkontrol dengan tidak melakukan hal-hal yang buruk, dan anak memiliki hubungan yang baik dengan keluarga maupun dengan teman-temannya.

Berkaitan dengan moral kejujuran, ibu SS mengungkapkan bahwa ia membimbing anak untuk selalu jujur. Jika anak mengucapkan sesuatu itu sesuai dengan kenyataan yang terjadi, namun juga kadang ada salahnya, ia sebagai orang tua harus tau dan peka jika anak tidak jujur, ia juga bisa merasakan. Jika anak meminjam barang milik orang lain, ia mengajarkan harus minta ijin, harus hati-hati, harus dikembalikan, dan mengucapkan rasa terimakasih. Ia mengajarkan anak untuk tidak pernah menukar barang punya sendiri dengan punya orang lain. Kalau ada soal yang sulit di sekolah ia melarang anak mencontek atau berbuat curang. Ia membiasakan anak harus belajar dengan tekun. Ia mengajarkan anak jika berbuat janji harus ditepati. Biasanya anak janjian main dengan teman. Hal tersebut juga diperkuat dengan hasil wawancara anak ibu SS yaitu CRAP yang mengatakan bahwa ia bicara jujur agar dapat dipercaya orang. Ia mengucapkan sesuatu sesuai kenyataan dan jika ada teman yang berbuat salah ia memaafkan. Ia jika di sekolah kadang-kadang mencontek tapi kalau sekarang pembelajaran daring tidak. Ia tidak pernah menukar barang punya sendiri dengan orang lain. Ia jika meminjam barang punya teman izin terlebih dulu. Hasil observasi menunjukkan bahwa
CRAP anak yang jujur, namun ada beberapa hal yang terkadang membuat anak tidak jujur. b. Pengrajin genteng

Keluarga bapak B merupakan seorang yang bekerja sebagai pengrajin genteng dan begitu juga istrinya yaitu ibu NM yang juga bekerja. Ibu NM dan bapak B kerja dari pukul 08.00-16.00 WIB. Pola asuh yang orang tua terapkan pada keluarga yang bekerja sebagai pengrajin genteng tidak semuanya memiliki pola asuh yang sama, tetapi mereka mempunyai cara yang berbeda. Orang tua yang bekerja sebagai pengrajin genteng umumnya bekerja di rumah atau di lokasi yang dekat dengan rumah. Cara pola asuh yang diungkapkan dari ibu NM mengatakan bahwa:

"Di rumah anak saya beri peraturan suruh belanja, masak, dan setelah selesai mau bermain baru saya bolehin. Anak di rumah saya didik moralnya dengan diajari yang baik. Kalau anak berbuat salah langsung dipukul, maksud bapaknya seperti itu biar tidak jadi anak nakal, tidak jadi anak yang kurang ngajar dan tidak sopan. Anak saya beri peraturan dan tidak boleh dibantah mbak. Kalau dibantah dipukul ringan. Kadang anak memang pernah melakukan kesalahan dan sering dicari kesalahannya. Kadang anak dan orang tua pernah berbeda pendapat. Anak saya buat disiplin dan kadang juga tidak. Anak cenderung saya paksa untuk berbuat sesuatu".

Berdasarkan hasil wawancara tersebut menunjukkan bahwa pola asuh yang diterapkan dalam keluarga tersebut adalah pola asuh otoriter. Pola asuh otoriter yang diterapkan di atas ditandai dengan ketika anak melakukan kesalahan anak akan dimarahi dan juga dipukul oleh bapaknya. Maksud bapak B agar anak tidak mengulangi kesalahan yang sama lagi. Orang tua memaksakan kehendak kepada anak. Hal itu membuat anak tidak 
bebas melakukan apa yang ingin dilakukan karena selalu diatur oleh orang tua. Hasil observasi menunjukkan bahwa anak berani melanggar peraturan, sopan santun anak kepada orang tua kurang baik, dan anak kadang berani berbohong.

Berkaitan dengan moral kejujuran, ibu NM mengungkapkan bahwa ia mengajari anak untuk mengucapkan ataupun bercerita tentang apapun sesuai dengan keadaan yang terjadi dan jika meminjam barang ia ajarkan untuk meminta izin dulu. Ia mengajari anak untuk tidak menukar barang punya sendiri dengan punya orang lain dan jika ada tugas yang sulit anak ia larang mencontek, tetapi biasanya minta bantuan bapaknya. Anak jika berbuat janji kadang ditepati kadang juga tidak. Hal tersebut juga diperkuat dengan hasil wawancara anak ibu NM yaitu DAW yang mengatakan bahwa ia tidak pernah dibimbing untuk dapat dipercaya oleh seseorang. Ia selalu mengucapkan jujur untuk hal-hal yang benar-benar terjadi tetapi terkadang juga pernah berbohong karena takut jika dimarahi. Ia memaafkan teman yang bersalah. Ia tidak pernah menukar barang punya sendiri dengan orang lain. Ia tidak pernah mencontek dan tidak pernah berbuat curang. Ia pernah membuat janji dan ditepati.

c. Karyawan pabrik

Orang tua yang bekerja sebagai karyawan pabrik umumnya bekerja dari pagi hingga sore dan jika ada lemburan bisa pulang sampai malam. Ibu NDN membagi waktu antara pekerjaan dan anak yaitu mengatur waktu untuk pekerjaan rumah dan bersama anak setelah habis kerja. Setiap orang tua dalam mengasuh anak mempunyai pola asuh yang tidak sama atau berbeda-beda. Namun dari setiap pola asuh yang diterapkan oleh orang tua walaupun berbeda, tetapi tujuan dari setiap orang tua sama bahwa menginginkan anak menjadi pribadi yang baik. Dibuktikan dengan salah satu hasil wawancara orang tua siswa yang bekerja sebagai karyawan pabrik yaitu ibu NDN yang mengungkapkan bahwa:
"Di rumah saya memberi peraturan pada anak. Saya juga memberi arahan mana perbedaan perbuatan baik dan buruk, mana yang harus dipertahankan atau ditinggalkan. Anak saya suruh meninggalkan perbuatan buruk seperti jika main jangan terlalu lama dan jangan sampai malam. Bermain ada waktunya untuk jam-jam tertentu, harus ingat waktu sekolah, dan anak juga saya suruh untuk mengantarkan dan menjemput adiknya sekolah. Memberi perhatian dan bimbingan kepada anak. Di keluarga hubungannya akrab karena komunikasinya selalu terjalin".

Berdasarkan hasil wawancara tersebut menunjukkan bahwa pola asuh yang diterapkan dalam keluarga tersebut adalah pola asuh demokratis. Orang tua memberi peraturan namun tetap memberi kesempatan pada anak untuk menentukan pilihan hidupnya dan tidak semua orang tua yang mengendalikan kehidupan anak. Hasil observasi menunjukkan bahwa AYS anak ibu NDN sangat aktif di kelas, sopan santun dengan guru maupun orang tua juga, selalu jujur mengerjakan tugas sekolah dengan usaha sendiri, AYS anak yang bicara dengan jujur apa adanya dengan orang tua, dan anak yang tanggung jawab dengan tugas yang diberikan oleh orang tua maupun gurunya.

Berkaitan dengan moral kejujuran, ibu NDN mengungkapkan bahwa ia membimbing anak untuk jujur dan setahu ia anak tidak pernah berbohong. Anak cerita atau mengatakan sesuatu sesuai dengan hal-hal yang benar terjadi. Ia tidak pernah mengajari anak untuk pinjam barang milik orang lain, meskipun punya sendiri itu jelek. Kadangkadang anak musuhan dengan temantemannya melalui whatsapp, kemudian ia beri pengertian pada anak untuk saling memaafkan. Ia mengajari jika diberi tugas dari sekolah dikerjakan sendiri, jika tidak bisa anak mencari tau melalui google dan tidak mencontek teman. Ia mengajari anak untuk 
menepati janji, misalnya waktu mau ketemu dengan temannya. Hal tersebut juga diperkuat dengan hasil wawancara anak ibu NDN yaitu AYS yang mengatakan bahwa ibu dan bapak selalu mengajari ia untuk jujur agar dapat dipercaya. Jika cerita atau mengatakan sesuatu ia selalu mengatakan yang benar-benar terjadi. Ia tidak pernah minjam barang milik orang lain. Jika teman ia berbuat salah ia memaafkan, tetapi kadang ia pernah tidak mau memaafkan karena teman ia sering nakal dengan AYS. Ia tidak pernah menukar barang punya sendiri dengan punya orang lain. Ia juga tidak pernah mencontek dan biasanya jika ia berbuat janji ia tepati. Hasil observasi menunjukkan bahwa moral kejujuran AYS cukup baik. AYS jika cerita dengan ibunya selalu bicara denga jujur apa adanya, AYS selalu mengerjakan tugas sekolah sendiri tanpa mencontek dan berbuat curang. Hal itu terlihat dari hasil belajar anak yang sering mendapat nilai bagus.

d. Penjahit

Ibu LS adalah seorang yang bekerja sebagai penjahit di rumah dan begitu juga suaminya yaitu bapak SM yang juga bekerja. Orang tua yang pekerjaannya sebagai penjahit di rumah umumnya memiliki lebih banyak waktu di rumah. Berikut ini ungkapan dari ibu LS yang mengatakan bahwa:

"Di rumah anak saya kasih peraturan tidak boleh main jauh-jauh. Saya batasin mainnya. Anak saya beri peraturan yang harus dipatuhi dan tidak boleh dibantah. Anak-anak kadang melakukan kesalahan, itu sering saya ingatkan kesalahannya selalu. Kalau anak berbuat salah saya kasih hukuman seperti uang jajan di kurangin, terus membersihkan rumah. Sering saya perintah untuk melakukan sesuatu, seperti saya suruh belajar. Larangannya itu anak saya larang main jauh-jauh. Sering berbeda pendapat dengan anak. Tidak terlalu memaksa anak untuk disiplin tetapi misalnya waktunya main dan sudah masuk jam sekolah, harus tau waktu dan pulang".

Berdasarkan hasil wawancara tersebut menunjukkan bahwa pola asuh yang diterapkan dalam keluarga tersebut adalah pola asuh otoriter. Pola asuh otoriter yang diterapkan oleh ibu LS dibuktikan ditandai dengan orang tua memberi peraturan sepihak, anak dihukum ketika melakukan kesalahan dengan tidak memberi uang jajan dan juga membersihkan rumah. Hasil observasi menunjukkan bahwa anak berani melanggar peraturan dari orang tua, anak menjadi penakut, kurang aktif di kelas, dan moral kejujuran anak masih rendah.

Berkaitan dengan moral kejujuran, Ibu LS mengungkapkan bahwa ia mengajarkan mengucapkan sesuatu yang benar-benar terjadi. Namun kadang anak takut jadi terpaksa pernah berbohong. Ia mengajarkan juga jika anak berbuat salah harus minta maaf. Hal tersebut juga diperkuat dengan hasil wawancara FAP yang mengatakan bahwa ia mengucapkan jujur agar dapat dipercaya siapapun. Ia sering tidak meminta izin jika minjam barang orang, seperti mengambil handphone orang tua tanpa izin. Ia sering memaafkan teman yang salah. Ia tidak pernah menukar barang punya sendiri dengan orang lain. Kadang-kadang ia pernah mencontek. Ia tidak pernah berbuat curang dan ia tidak pernah membuat janji. Hasil observasi menunjukkan bahwa FAP anak yang kurang aktif saat di kelas. Kadang anak mencontek pekerjaan teman jika tidak bisa mengerjakan.

Sebagai guru wali kelas $\mathrm{V}$, guru juga mempunyai peran membentuk moral anak agar anak memiliki kepribadian dengan tingkah laku yang baik, dan tercipta kehidupan yang damai. Hal tersebut juga didukung dengan hasil wawancara kepada guru wali kelas V yang mengungkapkan bahwa:

"Peran saya sebagai guru kelas membentuk moral anak dengan banyak memberi saran-saran, banyak 
memperingatkan kalau di rumah ikuti peraturan orang tua, jika di sekolahan dengan teman harus menghormati, dengan orang tua apalagi dan juga dengan guru. Saya sebagai guru memang tidak bosan-bosannya untuk selalu mengingatkan dan mengingatkan”.

Berdasarkan hasil wawancara menunjukkan bahwa guru selalu berusaha memberikan pengasuhan yang baik juga kepada anak dengan memberikan peranan salah satunya membentuk moral kejujuran anak. Tidak ada kata bosan bagi guru untuk selalu mengingatkan, mengarahkan, dan membimbing anak supaya memiliki moral yang baik, salah satunya adalah moral kejujuran. Guru juga memperingatkan anak untuk selalu mengikuti peraturan orang tua, dengan begitu anak juga mengikuti pola asuh yang diterapkan orang tua atas nasehat dari gurunya.

Hal lain yang juga diungkapkan oleh guru kelas bahwa moral kejujuran anak ratarata jujur. Namun ada yang masih rendah misalnya ketika mencocokkan pekerjaan tugas soal misal anak sebenarnya salah sekian tapi setelah ia panggil untuk memasukkan nilai anak mengatakan tidak sesuai salah berapa. Hal itu termasuk sudah tidak jujur.

Berdasarkan hasil uraian di atas, bahwa peneliti menemukan moral siswa pada indikator kejujuran adalah masih rendah pada beberapa indikator moral kejujuran tertentu. Pembentukan moral kejujuran oleh orang tua yang memiliki pekerjaan hampir setengahnya anak sudah memiliki moral kejujuran yang sudah baik namun perlu lagi untuk ditingkatkan. Anak kurang berani atau kadang berbohong mengatakan sesuatu tidak sesuai dengan kenyataan yang terjadi karena takut jika akan dimarahi oleh orang tuanya. Kejujuran adalah salah satu akhlak yang terpuji. Kejujuran mempunyai banyak hal positif untuk diri sendiri seperti dapat dipercaya orang lain, memiliki rasa tanggung jawab dan tentunya tidak akan merugikan diri sendiri maupun orang lain. Membentuk moral kejujuran membutuhkan bantuan keterlibatan tidak hanya pada satu pihak, tapi juga dari lingkungan yang sangat memberi pengaruh kepada anak yaitu lingkungan keluarga. Hal tersebut juga di dukung dengan temuan penelitian yang dilakukan oleh Inten (2017:45) bahwa kejujuran yang orang tua tanamkan melalui keteladanan dan contoh pada keseharian yang kerap dilihat anak akan mudah diingat dan tumbuh dalam diri anak. Setiap orang tua pasti memiliki pekerjaan yang dilakukan demi untuk memenuhi segala kebutuhan. Namun setiap pekerjaan apapun itu yang dimiliki orang tua siswa kelas $\mathrm{V}$ diatas seperti pengrajin genteng, pedagang, karyawan pabrik, dan penjahit, maka orang tua harus mampu mengatur waktu antara pekerjaan dan anak karena orang tua harus bisa memperhatikan dan membimbing perkembangan moral anak. Membentuk moral kejujuran bukanlah hal yang instan, membutuhkan waktu mengajari mulai dari hal-hal yang kecil. Berikut ini data hasil temuan penelitian yang dijabarkan pada bentuk tabel:

Tabel 1. Bentuk Pola Asuh Orang Tua Siswa Dan Moral Siswa

\begin{tabular}{ll}
\hline Pola asuh orang tua & Moral kejujuran siswa \\
\hline Pola asuh demokratis & Cukup tinggi \\
Pola asuh otoriter & Perlu ditingkatkan \\
\hline
\end{tabular}

Pola asuh yang dimiliki setiap keluarga berbeda-beda, apalagi dengan kesibukan orang tua yang juga bekerja. Sesuai cara berpikir orang tua, latar belakang hidup orang tua ataupun pengalaman orang tua sehingga hal-hal tersebut dapat berpengaruh dalam cara mengasuh atau mendidik anak di keluarga. Orang tua menerapkan pola asuh 
dapat mempengaruhi proses perkembangan pembentukan moral kejujuran anak. Hal itu di dukung dengan penelitian yang dilakukan oleh Agustina (2012:1) mengungkapkan bahwa pekerjaan orang tua dapat mempengaruhi perkembangan nilai moral, perilaku dan sikap siswa yang berkembang dan tumbuh didalamnya. Apabila jika orang tua salah dalam memberikan pola asuh dapat menyebabkan anak mempunyai moral yang buruk. Nilai-nilai moral yang orang tua tanamkan kepada anak, maka anak tidak akan jauh berbeda dengan yang orang tua ajarkan. Perkembangan moral anak yang utama bertanggung jawab adalah orang tua. Oleh karena itu, anak harus diarahkan perbuatan mana yang benar dan mana yang salah supaya anak mempunyai moral kejujuran yang berkualitas tinggi. Hal yang mudah dapat dilakukan dalam membentuk moral anak adalah dengan memberi contoh perilaku moral kebiasaan atau keteladanan yang baik secara langsung dalam kehidupan. Hal tersebut selaras dengan temuan penelitian yang dilakukan oleh Hafidhoh (2019:144) bahwa pola asuh orang tua dengan memberikan keteladanan mampu membuat anak untuk memahami moral yang diberlakukan di masyarakat. Apapun pekerjaan yang dimiliki orang tua dan dengan kesibukan yang dimiliki orang tua, apabila orang tua mampu memberikan pola asuh yang tepat kepada anak dan mampu membagi waktu antara bekerja dan anak, semua itu tidak menjadikan masalah.

\section{SIMPULAN DAN REKOMENDASI}

Berdasarkan hasil analisis dari penelitian yang sudah dilakukan tentang bentuk pola asuh orang tua yang bekerja terhadap pembentukan moral kejujuran bahwa bentuk pola asuh pada keluarga dengan jenis pekerjaan yang berbeda yaitu demokratis dan otoriter. Sedangkan berkaitan pada moral kejujuran siswa kelas V SDN 3 Mayonglor masih perlu ditingkatkan lagi. Hal tersebut dikarenakan pengasuhan orang tua yang bekerja waktunya banyak tersita pada pekerjaan sehingga kurang maksimal dalam membentuk moral kejujuran anak. Saran bagi orang tua siswa di kelas $\mathrm{V}$ diharapkan dapat memberikan pola asuh yang tepat pada anak dan juga dapat membimbing, membentuk, dan meningkatkan moral kejujuran pada anak dengan lebih baik lagi.

\section{DAFTAR PUSTAKA}

Adisusilo, S. (2013). Pembelajaran Nilai-nilai Karakter. Jakarta: Rajawali Pers.

Agustina, A. E. (2012). Pengaruh Pekerjaan Orang Tua terhadap Perilaku Sosial Siswa di SMP Negeri 1 Pabedilan Kecamatan Pabedilan Kabupaten Cirebon. Skripsi. Fakultas Tarbiyah. IAIN Syekh Nurjati Cirebon.

Azizah, I. N. (2019). Pengaruh Pola Asuh Demokratis Orang Tua terhadap Cara Bergaul Anak: Studi di Desa Derik, Susukan, Banjarnegara. Jurnal Studi Islam, Gender dan Anak, 14 (2), 329345.

Badria, E. R., dan Fitriana, W. (2018). Pola Asuh Orang Tua dalam Mengembangkan Potensi Anak Melalui Homeshooling di Kancil Cendikia. JURNAL COMM-EDU, 1(1), 1-8.

Daradjat, Z. (2012). Ilmu Pendidikan Islam. Jakarta: Bumi Aksara.

Dewayani, S. (2016). Agar Anak Jujur (Panduan Menumbuhkan Kejujuran kepada Anak Sejak Dini). Jakarta: Komisi Pemberantasan Korupsi RI Direktorat Pendidikan dan Pelayanan Masyarakat.

Djamarah, S. B. (2017). Pola Asuh Orang Tua dan Komunikasi dalam Keluarga. Jakarta: Rineka Cipta.

Fathurrohman. (2019). Implementasi Pendidikan Moral di Sekolah Dasar. Jurnal Bidang Pendidikan Dasar (JBPD), 3(1), 79-86.

Firdaus, S. A., dan Kustanti, E. R. (2019). Hubungan Antara Pola Asuh Otoriter dengan Pengambilan Keputusan 
Karier Pada Siswa SMK Teuku Umar Semarang. Jurnal Empati, 8 (1), 212220.

Hafidhoh, N. B. (2019). Pola Asuh Orang Tua dalam Membentuk Moral Anak. Tesis. Program Studi Pendidikan Agama Islam. Universitas Islam Negeri Sunan Ampel.

Hasanah, E. (2019). Perkembangan Moral Siswa Sekolah Dasar Berdasarkan Teori Kohlberg. JIPSINDO, 2 (6), 131-145.

Inten, D. N. (2017). Penanaman Kejujuran Pada Anak Dalam Keluarga. Jurnal FamilyEdu, 3(1), 36-45.

Jamaluddin, D. (2013). Paradigma Pendidikan Anak dalam Islam. Bandung: Pustaka Setia.

K. Bertens. (2016). Pendidikan Karakter Berbasis Keluarga. Depok: Arruzz Media.

Lickona, T. (2012). Mendidik untuk Membentuk Karakter. Jakarta: Bumi Aksara.

Meleong, L. J. (2014). Metodologi Penelitian Kualitatif. Bandung: Rosdakarya.

Mirantika, N. R. (2016). Hubungan Pola Asuh Permisif dan Otoriter dengan Kenakalan Remaja. Skripsi. FKIP. Universitas Negeri Semarang.

Rahardjo, M. (2017). Studi Kasus dalam Penelitian Kualitatif: Konsep dan
Prosedurnys. http://repository.uinmalang.ac.id/1104

Reskia, S, et al. (2014). Pengaruh Pendidikan Orang Tua terhadap Prestasi Belajar Siswa di SDN Inpres I Birobuli. Elementary School of Education EJournal, 2(2), 83.

Sari, C. \& Wahyuni, P. (2020). Pengaruh Pola Asuh Otoriter Orang Tua Bagi Kehidupan Sosial Anak. JURNAL PENDIDIKAN dan KONSELING, 2 (1), 76-80.

Satrianingrum, A. P., dan Andriyanti, E. (2020). Resiko Pengasuhan Permisif Orang Tua dan Nenek Pada Pencapaian Bahasa Anak. Jur. Ilm. Kel. \& Kons, 13 (3), 239-249.

Sukamto, R. N., dan Fauziah, P. (2021). Identifikasi Pola Asuh Orang Tua di Kota Pontianak. Jurnal Obsesi: Jurnal Pendidikan Anak Usia Dini, 5 (1), 923-930.

Shochib, M. (2014). Pola Asuh Orang Tua dalam Membantu Anak Mengembangkan Disiplin Diri. Jakarta:Rineka Cipta.

Yasbiati, et al. (2019). Profil Kejujuran Anak Usia 5-6 Tahun di RA-At-Taufiq Kota Tasikmalaya. Jurnal Pendidikan Anak, 8 (2), 99-106. 